\title{
Rational Choice Theory in Comparative Sociology
}

\author{
Hanno Scholtz \\ Department of Sociology, University of Konstanz, Germany \\ hanno.scholtz@uni-konstanz.de
}

\begin{abstract}
Among schools of thought in comparative research, Rational Choice Theory (RCT) is both the most systematic and the most contested. RCт lacks a "classical" foundation but offers a clear internal theory structure. The rationality assumption contains an unquestioned heuristic aspect, although the determinants of choice (especially preferences) lack a universally accepted solution. The choice aspect addresses the understanding of social phenomena as the result of individual actions seen in light of the possible alternatives. This view unifies scholars in the Rational Choice tradition and leads to the macro-micro-macro-scheme. Micro-oriented comparative research has flourished through the availability of multi-level data sets in fields such as social capital theory, social stratification and mobility, including educational attainment or the inclusion of migrants, family studies, criminology, and labor markets. Institutional RСт-based comparative research has addressed welfare states, religion, and general questions. In both aspects, RCT leaves room for further productivity in comparative research.
\end{abstract}

\section{Keywords}

rational choice theory - comparative research - sociology of knowledge - sociological explanation - social capital - institutions

Rational Choice Theory (RCT) is among the most important schools of thought in comparative research and it is probably the most systematic, as well as the most contested.

While many schools of thought are characterized by the use of a specific "classic", a seminal author like Marx or Bourdieu whose wisdom has sparked an entire school of thought, this idea is wholeheartedly dismissed by the 
proponents of RCT - although internal dynamics of science have led James Coleman and Gary S. Becker to some sort of "classical" status for RCT.

Since the 1990s, many good articles reviewing the general development of RCT have been published (see, e.g., Hechter and Kanazawa 1997; Edling and Stern 2003; Hedström and Stern 2008; Raub, Buskens, and Van Assen 2011; Kroneberg and Kalter 2012). Consequently, the present assessment concentrates on some questions particularly relevant for comparative research. The available reviews, however, all share a similar tendency to consider the normative understanding of science as a value-free accumulation of knowledge of reality. Although RCT generally embraces the perspectice that social facts are shaped by all-too-human actors who have their own specific rationality, this perspective is not yet incorporated into these reviews, as they fail to acknowlege that science is also shaped by human actors. Since it is helpful for comparative scholars to understand such dynamics, the second aim of the article is to describe RCT in a way that allows one to understand why it is relatively underestimated in contemporary comparative research.

To understand the position of RC sociology today, it is worthwhile to review the formation of the disciplinary organization of the science that mirrors the advent of differentiation in the nascent industrial society. While Adam Smith ([1776] 1976) and Karl Marx ([1867] 1993) viewed the totality of social interaction, the late 19th century saw the emergence of clear disciplinary distinctions, notably between sociology and economics. This disciplinary distinction was underlined by the fact that the emerging "modern" enterprises worked as systems of bureaucratic rule, making them "iron cages" from the inside but appearing as rational actors from the outside (Weber 1922). These systems were suitable for an economic analysis that concentrated mainly on price relations (Walras 1874), abstracting from all social embeddedness of economic action. In the 1940s, scientists from both sides of the cleavage accepted a clear division of labor that addressed to economics an ever more sophisticated formal analysis based on actors, rationality and full information. Sociology, on the other hand, ${ }^{1}$ took an internally divided part: On the one hand holistic verbal theorizing about emergent phenomena that related abstract concepts

1 The description simplifiees a bit. For example, the reception of game theory in sociology was thin but existed (Vinacke and Arkoff 1957; Gamson 1961), and the works of Robert K. Merton 
without considering individual action, especially in comparative studies; on the other an emerging survey science with a tendency to rather a theoretical data collection.

RCT addressed this situation as creative provocation, in almost chronologically parallel steps by Becker and Coleman, which both started the common intellectual enterprise in 1957 with studies on discrimination and diffusion (Becker 1957; Coleman, Katz, and Menzel 1957). The next big steps came in 1964 with Becker's Human Capital that interpreted education as mere capital accumulation, and Coleman's Introduction to Mathematical Sociology that declared the use of mathematics in sociology as useful, if not necessary (Becker 1964; Coleman 1964), and the late 1960s with Becker's article on crime (Becker 1968) and the "Coleman report" on equality of educational opportunities (Coleman and NCES 1966). After 1973, Coleman and Becker taught together in Chicago but their pace differentiated. While Becker in equally paced steps intensified the intellectual provocation by saying (Becker 1977) and practically underlining (Becker 1981; Becker and Murphy 1988) his conviction that the toolbox of formal economics contained everything necessary to understand the social world, Coleman was more preoccupied with the aftermath of applying his way of theorizing to the practical world in his "Coleman report" and the subsequent busing policies in the 1970s, and later published his major insights at a fast pace before retiring. (Coleman 1986; 1988; 1990) At the same time, RCT developed in Europe through a network of scholars such as Raymond Boudon, Hartmut Esser, Karl Dieter Opp, Siegwart Lindenberg, and others. (Hummell and Opp 1968; Boudon 1974; 1982; Opp and Hartmann 1989; Lindenberg 1990; Esser 1996; 1999-2001). ${ }^{2}$ The influence, however, of both Europeans and of others working in the United States, most notably Michael Hechter and Jon Elster (Elster 1989; Hechter and Kanazawa 1997), falls short of the contributions of Coleman and Becker, both in terms of defining Rational Choice internally and even more so in making a provocative case for the outside world.

RCT challenged the disciplinary organization of science: Becker was an economist, and Hummell and Opp declared (in their title - the content of their text was more balanced) the whole of sociology irrelevant. All Rational Choice sociologists abandoned the structuralist thinking that had been central

([1942] 1966) and George C. Homans (1961) prepared the ground for RC theory, but without ostensibly bridging the methodological divide.

2 It should be noted that these scholars have, to a large extent, published in their native languages. Especially Hartmut Esser, as this strategy has made him a leading figure for a whole generation of German sociologists. As his work has not yet been translated, it is almost inaccessible internationally. 
to sociology's self-conception in the 1950s and 196os. Although this obvious provocation was short-lived, RCT was provocative for sociology in more than this superficial way.

The term Rational Choice addresses two related aspects of a deeper intellectual provocation in sociology. The term "choice" implies understanding social phenomena as result of individual action, and that every action is seen as a choice, in a counterfactual view, in light of its possible alternatives. Describing these choices as "rational" implies deducing them from actor characteristics other than the action itself.

A third aspect should be added that is theoretically neither necessary nor sufficient, but nevertheless closely links the two and is of large practical importance. This aspect acknowledges that choice, as related to actor characteristics, is in many cases analyzed as some form of quantifiable optimization problem, hence RC sociology uses mathematical tools such as differential calculus or game theory. This is a distinction that cannot be underestimated in its practical relevance. In a world where many sociologists are happy to abandon every contact with formal notation after having passed their statistics exams, this is a massive provocation, too. It also reduced complexity using the clear advantages that formal theories have for deriving solutions for well-formulated complex problems. But the systematic aspects are the first two mentioned. They are the focus of this paper.

The Macro-Micro-Macro Scheme

Of the two systematic aspects, the first unifies scholars in the Rational Choice tradition and defines the distinctive contribution of RCT to comparative sociology. It is illustrated by the macro-micro-macro scheme, made famous by "Coleman's boat" in Figure 1 below.

A: Macro-conditions

D: Macro-outcomes

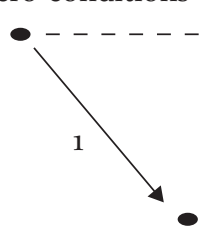

4

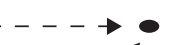

B: Micro-conditions

C: Micro-outcomes

reprinted from Raub, Buskens, and Van Assen (2011, p. 3).

FIGURE 1 The macro-micro-macro scheme of sociological explanation. 
This scheme was first described by Lindenberg in 1977 (Lindenberg 1977; Lindenberg and Wippler 1978) and later introduced to a wider audience by Coleman (1986). However, the very idea is much older, going back to the beginnings of the discipline itself, as its three arrows clearly correspond to Weber's definition of sociology as "a science which attempts the interpretive understanding of social action" (arrow 1) "in order thereby to arrive at a causal explanation of its course" (arrow 2) "and effects" (arrow 3). This fact is underlined by Coleman, who exemplifies the scheme using Weber's Protestantism thesis.

In Coleman's scheme, the letters A to D denote specific conditions on the macro (A and D) and the micro level (B and C). The dashed arrow 4 links propositions about macro-conditions (A) and macro-outcomes (D), in Weber's example Protestantism and modern capitalism. This is the proposed theoretical link in traditional macro-comparative research, and it is dashed in the figure to denote the pretension that links of this kind can be established if and only if arrows 1 through 3 can be substantiated. Both the macro-outcome $D$ and the empirical regularity of arrow 4 are taken as given and have to explained through the remaining three nodes and arrows.

For these three arrows of the true "boat" (in Coleman's original figure, arrow 4 was not even drawn), the respective Dutch and German RCT schools have established different terminologies (Lindenberg 1977; Esser 1996; 1999-2001; Raub, Buskens, and Van Assen 2011). Node B represents specific conditions at the level of individual actors, ${ }^{3}$ and arrow 1 represents assumptions on how social conditions affect these variables. In Weber's Protestantism case, it is the question of how Protestant theology affected individual Protestants in the 17th and 18th centuries, with the doctrine of divine predestination and the related paradoxical result that thrift and success are socially rewarded at its core.

Here, and in many other examples of comparative sociology, this first arrow demands the highest scientific effort and results in the most important scientific achievement. The first arrow selects from the whole cosmos of social complexity those specific aspects of an individual's situation that make the difference when it comes to the understanding of social action and the resulting macro-sociological outcomes as mere derivations. Lindenberg and the Dutch school call this arrow "bridge assumptions", Esser and his German students speak of a "logic of the situation".

Node C describes the resulting individual action. Based on some general theory of action, these case-specific situational aspects resulting from arrow 1 are assumed to be converted, in arrow 2, into a specific choice of action. In

3 Although the theory uses a terminology that is also applicable to organizations on the lower level, the normal use is with human individuals as micro actors. 
Weber's case, it is the general assumption that people are interested in a higher status, and hence choose thrift and success as actions that are socially rewarded. We speak of "assumptions on individual behavior" (Lindenberg) or of the "logic of selection" in Esser's terms.

Node D represents the final outcome on the macro level that becomes realized through arrow 3 , namely the aggregation of individual actions $\mathrm{C}$. In the example of the emergence of capitalism, it is the combination of thrift and success orientation that creates both the social supply of saving and the social demand for investment that allows the conversion of the early modern advances in scientific knowledge into the machines that made the industrial revolution possible. As in this case, these "transformation rules" (Lindenberg) or "logic of aggregation" (Esser) can be more or less trivial or known from the outset, but they can pose their own specific demands on scientific formulation.

This aspect of choice in Rational Choice is the common denominator of all scholars in the tradition founded by Coleman and the other pioneers mentioned. It has spread widely, as reflected in the fact that the bold term "sociological explanation" is used by its proponents (Norkus 2000; Esser 2006; Stolz 2011) and not really questioned by opponents. ${ }^{4}$

This definition however was another provocation for sociology in the 1980s. Neither of the earlier leading paradigms of Structural Functionalism or Marxism had left much room for individual choices. Qualitative sociology was interested in individuals but not from the viewpoint of choice, even after Coleman published his 1986 paper. Despite being well-versed in the analysis of individual data, Melvin L. Kohn in his presidential address for the ASA (Kohn 1987), completely ignored the fact that even nations as units of analysis are determined by social facts established through the actions of the individuals contained within those nations. He also failed to recognize that shedding light on these actions allows a comparision to the possible alternatives. Older comparative sociology in many cases had adopted individual-level considerations, but more in an illustrative way than any systematic fashion. While an illustrative way of individual-level consideration allows us to point to different mechanisms which may underlie the same macro-level connection, RCT demands clear decisions about the mechanism(s) which are seen as being causally responsible. This demand makes RCT models clearer and hence adds to the accumulation of knowledge. But it questions the former status of sociologists as great narrators.

4 One serious attempt at questioning the equalization of the term "sociological explanation" with individual-level mechanisms, was undertaken by Jepperson and Meyer (2011). 
The larger provocation, however, lay in the second aspect contained in the term "Rational Choice", namely the description of choices as "rational". In relation to the former aspect of sociological explanation, this aspect is contained in the second arrow, the assumptions on individual behavior or logic of selection. It was not only the provocation that sparked the most heated repudiation from opponents of the approach in general, but this aspect also divides internally, among the scholars of Rational Choice, beyond the divisions of language that have been reported before.

The choice of a specific action rests on how the individual situation is described. With regards to this description, a threefold heuristic is established. This trinity results from the perspective of action as choice under insecurity, an insecurity that is ubiquitous but stems mainly from the uncertainty of interaction with others. Choice implies that (1) different options are compared, and which options are available can be summed up as a first characteristic of the actor. The second characteristic (2) is how these options are compared. They depend, however, in many cases on the different states the world may take, hence (3) including what actors think about the probabilities for these different states of the world has to be included.

Once again, different terms have be used in the history of the Rational Choice tradition, which are condensed in Table 1 . The first is that of game theory where the choice of individual actions depends on (1) the strategies available, (2) the pay-offs related to possible combinations of individual actions, and (3) the expectations with regards to the actions of others (Gintis 2000). Esser uses the terms (1) resources, (2) motivations, and (3) expectations, (Esser 1999-2001) but the triplet was only examined more intensely by Peter Hedström (Hedström 2005) who uses the terms (1) opportunities , (2) desires, and (3) beliefs, summed up in another sequence as "рво theory". The motivational aspect (2) is additionally described in terms of goals and preferences.

The terms for each of the three aspects are generally not identical, but they are in fact interchangeable in the study of individual choices, as can be shown in the most diverse case of the motivational aspect. The five terms mentioned here differ in ordinality and generality, but with regards to individual choices have to be condensed into their specific and ordinal correspondents. Substantially, the term preferences is the most appropriate. But the understanding of preferences demands generally what the other terms demand only in specific cases, and hence directs one to the problematic and divisive aspect of rationality.

The Latin term "ratio" means reason, and the reasons for an individual to pursue a specific action lie in all three aspects of their situation. Using this 


\begin{tabular}{llll}
\hline Author(s) & Aspect 1 & Aspect 2 & Aspect 3 \\
\hline $\left.\left.\begin{array}{l}\text { Game theory } \\
\text { Economists } \\
\begin{array}{l}\text { Opp } \\
\text { Esser } \\
\text { Hedström }\end{array}\end{array}\right\} \begin{array}{l}\text { strategies } \\
\text { pay-offs } \\
\text { preferences } \\
\text { goals } \\
\text { motivations } \\
\text { desires }\end{array}\right\}$ \\
opportunities
\end{tabular}

understanding of "rational" choice as "reasonable" choice is largely uncontested. However, the use of the adjective "rational" has diverted from this encompassing and humble perspective. Rationality, in terms of the adjective implied both in everyday usage and scientific language, assumes completeness, transitivity and stability, although a large body of experimental research has proven the ever-existing sociological conviction that not all social behavior is driven by preferences conforming to these assumptions (Fehr and Fischbacher 2003; Eckel and Gintis 2010; Rand and Nowak 2013). However that Gary Becker and the early RCT took these economic assumptions as fact is generally known, and this excessive creed made it easy for sociologists who felt uneasy about the math provocation and the mechanism provocation to dismiss the entire enterprise as unsociological. For some time the term 'rational choice' was used more among opponents (e.g. Zafirovski 1999; 2000) as a signal to evoke memories of this violation of good conduct expectations - of which scholars in the Rational Choice tradition are themselves aware.

One result has been that scholars in the Rational Choice tradition have for some time avoided the term 'rational choice' themselves, speaking instead of 'rational action' (Goldthorpe 1998), 'methodological individualism' (Udehn 2001; 2002), 'structural individualism' (Hedström and Bearman 2009b), or of 'analytical sociology' (Hedström 2005; Hedström and Bearman 2009a). Esser introduced the term 'frame selection' for a specific reformulation of the theory (Esser 1996; 1999-2001; 2006; Esser and Kroneberg 2010). But regardless of all these additional terms, 'rational choice' is still the most widely used.

In practical application, the term 'rational choice theory' has survived all the competition. A current Web of Science search through texts published since 2012 yields 658 hits for 'rational-choice', compared to 67 for 'frameselection', 58 for 'rational-action', 41 for 'methodological-individualism', and 19 for 'analytical-sociology' (and the predominance of the term holds for other 
search specifications). This is most likely because the alternatives such as 'sociological explanation' or 'analytical sociology' are very broad and unspecific and open to misunderstanding, while 'frame selection' is too narrow (Rössel 2008), and 'methodological individualism' or 'rational action theory', although substantially more correct, miss pointing out the specificity of the choice perspective.

The only thing that can be firmly said is: Preferences conform to the historic assumptions in many situations, however they do not always conform to them. Rationality is not only instrumental rationality, as altruistic behavior, identity, cognitive biases and other "irrationalities" exist in a way naïve RCT did not imagine. There is not yet a consistent theory of preference formation and how preferences depend on social situations. Experimental evidence has brought a broad input and some parts of a theory, and some interesting models have been created (Hechter 1994; Braun and Gautschi 2014), but RCT is far from a consensus that could replace the old narrow conception of rationality. On the other hand, norms and institutions that have been seen as obstacles to Rational Choice could be analyzed to a very large extent even using "old" RCT assumptions, but of course, the mentioned problems with regards to preference formation also exist here.

In the practical case when two alternative models are concurrently tested with empirical data which differ in the amount to which preferences are fixed, the results are likely to fit more with the more a-priori given preferences of the old Rational Choice model (Hakim 2002). But in a broader view, both belong to a wider Rational Choice paradigm as described here for the usage within comparative sociology. From an internal viewpoint, it may be useful to point out that frame selection or analytical sociology differ from each other and from what has been perceived as Rational Choice in the 1980s. But from the viewpoint centered on the usefulness for and practical application within comparative sociology, it is not.

Based on these considerations, we can now turn to the practical use and application of Rational Choice concepts in comparative sociology.

An important negative contribution of RCT to comparative sociology has to be mentioned: The wide reception of the macro-micro-macro scheme among quantitative sociologists have led to a systematic non-reception of panel-econometric conceptions of macro-empirical causality (Engle and Granger 1987) in comparative sociology, leaving this field almost entirely to economics and political science, even with regards to genuinely social target variables.

The positive contribution of RCT, however, can be roughly grouped into research where aggregation is simple and the research is almost completed 
on node $\mathrm{C}$, and research where the focus is on node $\mathrm{D}$, with aggregation a serious question. Practically, the first cluster is characterized to a large extent through the work with large multi-level data sets, while the second is almost completely tied to institutions. Since, however, factual comparative research in the multi-level cluster is largely tied to areas of research where RCT has been added to solve nontrivial aggregation problems, it is necessary to start the analysis by turning to the relation of Rational Choice and institutions in comparative research.

\section{Applied Comparative Research using Rational Choice}

The first cluster has flourished through the numerous attempts to collect multi-level data that obtain information from individuals in many national (and sometimes sub-national) societies. The well-known Luxembourg Income Study (since 1979), European Values Study and World Values Surveys (since 1981), International Social Survey Program (ISSP) (since 1985), or the comparative longitudinal Cross-National Equivalent File (since 1980) are today only the top few of a list that comprises roughly 100 studies. $^{5}$

In most cases finding the individual choices of actions in different national contexts is equivalent to finding the comparative outcome: If individuals are more religious, this is aggregated to the macro-social finding of higher religiosity; if they report a more traditional division of labor for individual household chores, this is aggregated to the macro-social finding of more traditional gender roles; if individual careers are more strongly tied to individual background, this is aggregated to the macro-social finding of less social mobility. In the rare cases where aggregation is a less trivial task, studies using the data are grouped in the second part of the review as well. Questions that are tackled by other comparative evidence, e.g. multi-national experimental designs (Rothstein and Eek 2009), are also categorized here.

The link between RCT and quantitative data analysis has been underlined by John Goldthorpe's pleading "for a sociological alliance" of the two, in which he demands that predictions of RCT should be tested using large-scale quantitative data, while also explaining theoretical narratives for statistical regularities found in using such data (Goldthorpe 1996). Although it can be argued that this alliance is not without alternative (Edling 2000), Goldthorpe's plea has nevertheless found wide reply. Quantitative research to a large extent uses $\mathrm{RCT}$, sometimes as central theoretical base, but more often as theory comparison in which some form of RCT assumptions (in most cases narrow) are tested

5 A continuously updated list is available on www.gesis.org/ComparativeSurveyOverview. 
against others that depart from other theory traditions, also true in applied comparative research.

Despite this general connection between RCT and multi-level statistical analysis, the practical use of Rational Choice in comparative research is highest in areas where Rational Choice scholars have made substantial theoretical contributions that laid the foundations for subsequent comparative research.

Social capital theory is probably the main success story of RCT in the $1990 \mathrm{~s}$ and 2000s. Although originally developed in the context of Bourdieu's theory of capital types (Bourdieu 1986) that was inspired by Marxist thinking and not at all related to individual choices, the concept was soon afterwards transformed through Coleman's paper on the relation of human capital and social capital (Coleman 1988). It turned into one of the main areas of research for scholars applying Rational Choice principles, allowing for the linkage to network studies (Lin 1999; Burt 2000). It has to be said, however, that the theoretical clarity of the Rational Choice argumentation is not equally used in the different contributions to the comparative literature on social capital.

For example, Paxton's studies about the positive effects of social capital on democracy has a clear theoretical foundation, posing that voluntary associations connected to other voluntary associations are more beneficial for the creation of generalized trust than associations isolated from other associations. He found that indeed more connected voluntary associations increase trust while more isolated associations decrease trust (Paxton 2002; 2007).

With regards to the effects of the state on social capital, either generally or with regards to welfare state type or size, the dynamics stem from contributions that focus on empirical insights (Kaariainen and Lehtonen 2006; Van Oorschot, Arts, and Gelissen 2006; Van Oorschot and Finsveen 2009; Robbins 2011) or from those, like Paxton, that apply more structural scrunity, e.g. by providing mechanisms linking the size of the welfare state and social capital (Sonderskov 2011; Sonderskov and Daugbjerg 2011; Gelissen, van Oorschot, and Finsveen 2012). One special case is Ferragina's tackling of Putnam's (Putnam, Leonardi, and Nanetti 1993) argumentation regarding the historical origins of social capital differences in a comparative perspective. This case results in the suggestion that current aspects, like income distribution, labour market participation and national cohesion, have much more impact than in medieval history (Ferragina 2013). Another direction is the experimental approach to the effects of different levels of experienced trustworthyness on trust in specific situations (Rothstein and Eek 2009).

Another successful example of applying RCT in quantitative comparative research is that on social stratification and mobility. The most important subfield is educational attainment, where Breen and Goldthorpe (1997) described 
the central model for conditions of social immobility. This model has sparked the empirically sound understanding of the comparative relation between education systems and differentials in educational attainment (Breen and Jonsson 2005; Bol and van de Werfhorst 2011; Montt 2011; Le Donne 2014) and the specific effects related to it (Kreidl and Hubatkova 2014). What is true for those in a socially stratified background also holds for studies regarding the inclusion of migrants in educational attainment (Teltemann and Windzio 2011; Verwiebe and Riederer 2013).

The sociology of the family has been both fertile and a battleground for Rational Choice sociology since Becker's highly controversial application of neoclassical economics to the aspects of family life. One specifically relevant subfield in comparative research where Becker's provocation (Becker 1981) is still both helpful and contested is research on the division of household labor. Despite the argument that men try to influence the division of chores by setting symbolical standards (Brines 1994), comparative literature has emphasized arguments that are more directly related to RCT, such as the role of domestic technologies, economic inequalities and more generally the broader social and economic structure (Heisig 2011; Van der Lippe, De Ruijter, De Ruijter, and Raub 2011), institutional restrictions (Hook 2006; Cooke and Baxter 2010; Hook 2010), and the relative resource distribution within the couple (Eeckhaut, Stanfors, and Van de Putte 2014).

Crime is likewise a field that strongly benefitted from the early provocation of Becker (Becker 1968) who freed the study of the subject from analytical restriction to norm deviation. It is, however, a field in which the limits of applying classical narrow RCT are most visible. Comparative research has concentrated on the effect of the intertemporally varying availability of resources from noncrime activities (Rosenfeld and Messner 2009) and to social capital effects on crime (Robbins and Pettinicchio 2012).

The sociology of the labor market is a subfield that is studied using Rational Choice approaches due to the proximity to economic research, again with Becker's original contribution (Becker 1964) as important driver. One important subfield here is female labor participation (Hummelsheim and Hirschle 2010), another the integration of young people into the labour market and the level of youth unemployment (Harslof 2006). A third subfield centers around the effects of social capital (Gesthuizen and Scheepers 2010), education (Carbonaro 2006; Gesthuizen, van der Meer, and Scheepers 2008; Reimer, Noelke, and Kucel 2008) and continued training (Dieckhoff 2007) on labor market chances, while a forth centers on the "scarring" effects of unemployment on future labor market integration (Gangl 2006), which exhibits notable cross-country differences (Dieckhoff 2011). 
Institutions is a term so general and so generic to sociology that Emile Durkheim has described the whole subject simply as "the science of institutions, of their genesis and of their functioning" (Durkheim [1895] 1973). ${ }^{6}$ When Becker wrote on crime (Becker 1968) the term institution was used only for prisons, and this and other examples of early RСт have led to the perception of Rational Choice being at odds with institutions. In fact, RCT has helped to develop a more precise understanding of institutions and the individual choices that underlie them than approaches that center on institutions and their effects alone. Starting from Axelrod's studies on the evolution of cooperation (Axelrod 1984; 1986), a Rational Choice approach to institutions understands them as "humanly introduced constraints" on human behavior (North 1990) or, more specifically, as a combination of new elements in the game structure of human interaction and with new Nash equilibria arising from these elements (Scholtz 2015).

This perspective allows one to address a wide array of comparative questions, both theoretically and empirically.

Much more specific are applications in the area of comparative welfare state research. To answer the question as to why welfare states have chosen so many different institutions, RCT adds to the explanation of institutional differentiation. Based on RCT, two mechanisms have been proposed, one based on differentiated power costs and power asymmetries (Korpi 2001), the other on contingent consent (Rothstein 2001). Empirical research does not yet allow a clear differentiation between the two (Dallinger 2008), but the models clearly have informed quantitative studies about welfare state convergence (Montanari, Nelson, and Palme 2008; Vrooman 2012).

Another specific application regards religious institutions and individual(s) behavior towards them. In the 1990s, choice-oriented considerations were brought into the sociology of religion, with religion as a specific social production for specific social demands (Iannaccone 1992; 1994; Hechter 1997; Young 1997; Stark and Finke 2000). This has stimulated a large body of comparative research (Gill 1999; Scheepers, Gijsberts, and Hello 2002; Ruiter and van Tubergen 2009; Aarts, Grotenhuis, Need, and De Graaf 2010; Stolz 2010; Lehmann 2013; Vane and Stipkova 2013).

6 Originally published in French: "La sociologie peut être [.] définie comme la science des institutions, de leur genèse et de leur fonctionnement". The translation follows (Thompson [1985] 2005). 
More general results include the description of historical path dependencies as social agreements in situations with a priori multiple equilibria (Mahoney 2000), or a so-called "grammar" of institutions that differentiates between formal and informal sanctions (Crawford and Ostrom 1995; Schlüter and Theesfeld 2010).

A Mertonian preoccupation with theories of the middle range in RCT has, however, limited the usage of the theory with regards to longer historical tendencies. One exception is Hechter's identification of a trend from class politics to cultural politics (Hechter 2004). The general finding that theories of social change and current transformations could to a larger extent be grounded in RCT and hence described as a constellation of specific social mechanisms has been mentioned (Esping-Andersen 2000; Aakvaag 2013), but so far without resonance.

\section{Conclusion}

In an attempt to describe the situation of current RCT in comparative sociology, we have turned to a combination of systematical and historical perspective. RCT originated as provocation against the disciplinary organization of science, as a provocation against former practice, especially in comparative sociology, as a provocation against the ignorance of formal theorizing in sociology, and as a provocation in the name of narrow rationality assumptions. While the last has made room for a broad internal discussion among Rational Choice theorists which has largely questioned but never successfully replaced the term 'rational choice' itself, the other three provocations remain productive for comparative research. Although the old narrow conceptions of rationality, especially in terms of preferences, have not yet been replaced by new generally accepted theory of human action, the Rational Choice perspective allows a systematic treatment that is open both to theoretical scrutiny and the usage of diverse, although most often quantitative, data. Although being declared dead more often than any other (less provocative) theory, Rational Choice Theory is still alive and still productive for comparative research.

\section{References}

Aakvaag, Gunnar C. 2013. "Social mechanisms and grand theories of modernity worlds apart?" Acta Sociologica 56:199-212.

Aarts, O., M. T. Grotenhuis, A. Need, and N. D. De Graaf. 2010. "Does duration of deregulated religious markets affect church attendance? Evidence from 26 religious mar- 
kets in Europe and north America between 1981 and 2006." Journal for the Scientific Study of Religion 49:657-672.

Axelrod, Robert. 1984. The evolution of cooperation. New York: Basic Books. . 1986. "An evolutionary approach to norms." American Political Science Review 80:1095-1111.

Becker, Gary S. 1957. The economics of discrimination. Chicago: University of Chicago Press.

-1964. Human capital: A theoretical and empirical analysis, with special reference to education. New York: National Bureau of Economic Research.

- 1968. "Crime and punishment: An economic approach." Journal of Political Economy $76: 169-217$.

- 1977. The economic approach to human behavior. Chicago: University of Chicago Press.

-1981. A treatise on the family. Chicago: Chicago UP.

Becker, Gary S. and Kevin M. Murphy. 1988. "A theory of rational addiction." Journal of Political Economy 96:675-700.

Bol, T. and H. G. van de Werfhorst. 2011. "Signals and closure by degrees: The education effect across 15 European countries." Research in Social Stratification and Mobility 29:119-132.

Boudon, Raymond. 1974. Education, opportunity and social inequality: Changing prospects in Western society. New York: John Wiley.

1982. The unintended consequences of social action. New York: St. Martin's.

Bourdieu, Pierre. 1986. "The forms of capital." Pp. 241-258 in Handbook of theory of research for the sociology of education, edited by R. J. Richardson. New York: Greenwood.

Braun, Norman and Thomas Gautschi. 2014. "Zwei Seelen wohnen, ach! In meiner Brust. Ein Rational-Choice-Modell innerer Konflikte ("Two souls, alas!, are dwelling in my breast": A rational choice model of inner conflicts)." Zeitschrift für Soziologie 43:5-30.

Breen, R. and J. O. Jonsson. 2005. "Inequality of opportunity in comparative perspective: Recent research on educational attainment and social mobility." Pp. 223-243 in Annual review of sociology, vol. 31, Annual review of sociology. Palo Alto: Annual Reviews.

Breen, Richard and John H. Goldthorpe. 1997. "Explaining educational differentials: Towards a formal rational action theory." Rationality and Society 9:275-305.

Brines, Julie. 1994. "Economic dependency, gender, and the division of labor at home." American Journal of Sociology 100:652-688.

Burt, Ronald S. 200o. "The network structure of social capital." Research in Organizational Behaviour 22:345-423.

Carbonaro, W. 2006. "Cross-national differences in the skills-earnings relationship: The role of labor market institutions." Social Forces 84:1819-1842.

Coleman, James S. 1964. Introduction to mathematical sociology. London: Free Press. 
. 1986. "Social theory, social research, and a theory of action." American Journal of Sociology 91:1309-1335.

- 1988. "Social capital in the creation of human-capital." American Journal of Sociology 94:S95-S120.

-1990. Foundations of social theory. Cambridge, Mass.: Belknap.

Coleman, James S., Elihu Katz, and Herbert Menzel. 1957. "The diffusion of an innovation among physicians." Sociometry 20:253-270.

Coleman, James S. and United States Office of Education National Center for Education Statistics NCES. 1966. Equality of educational opportunity. Washington: U.s. Dept. of Health, Education, and Welfare, Office of Education.

Cooke, L. P. and J. Baxter. 2010. “'Families'” in international context: Comparing institutional effects across Western societies." Journal of Marriage and Family 72:516-536.

Crawford, Sue E. S. and Elinor Ostrom. 1995. "A grammar of institutions." American Political Science Review 89:582-600.

Dallinger, Ursula. 2008. "Rationale Kooperation oder Moral? Der Wohlfahrtsstaat aus der Sicht der ökonomischen Institutionentheorie (Rational cooperation or cultural norms? The welfare state in the light of economic institutionalism)." Soziale Welt 59:157-179.

Dieckhoff, M. 2007. "Does it work? The effect of continuing training on labour market outcomes: A comparative study of Germany, Denmark, and the United Kingdom." European Sociological Review 23:295-308.

- 2011. "The effect of unemployment on subsequent job quality in Europe: A comparative study of four countries." Acta Sociologica 54:233-249.

Durkheim, Émile. [1895] 1973. Les règles de la méthode sociologique. Paris: Presses Universitaires de France.

Eckel, C. and H. Gintis. 2010. "Blaming the messenger: Notes on the current state of experimental economics." Journal of Economic Behavior \& Organization 73:109-119.

Edling, Christopher. 200o. "Rational choice theory and quantitative analysis. A comment on goldthorpe's sociological alliance." European Sociological Review 16:1-8.

Edling, Christopher and Charlotta Stern. 2003. "Scandinavian rational choice sociology." Acta Sociologica 46:5-16.

Eeckhaut, M. C. W., M. A. Stanfors, and B. van de Putte. 2014. "Educational heterogamy and the division of paid labour in the family: A comparison of present-day Belgium and Sweden." European Sociological Review 30:64-75.

Elster, Jon. 1989. Nuts and bolts for the social sciences. Cambridge: Cambridge University Press.

Engle, Robert F. and Clive W. J. Granger. 1987 "Cointegration and error correction: representation, estimation, and testing." Econometrica 55:251-76.

Esping-Andersen, G. 200o. "Two societies, one sociology, and no theory." British Journal of Sociology 51:59-77. 
Esser, Hartmut. 1996. “Die Definition der Situation.” Kölner Zeitschrift für Soziologie und Sozialpsychologie 48:1-34

-1999-2001. Soziologie: Spezielle Grundlagen, vol. 1-6. Frankfurt: Campus.

. 2006. "Eines für Alle(s)? Das Weber-Paradigma, das Konzept des moderaten methodologischen Holismus und das Modell der soziologischen Erklärung (One for all? The Weber paradigm, the moderate methodological holism concept and the sociological explanation model).” Kölner Zeitschrift für Soziologie und Sozialpsychologie 58:352-363.

Esser, Hartmut and Clemens Kroneberg. 2010. "Am besten nichts Neues? (Fortunately, all quiet on the theory front?)." Kölner Zeitschrift für Soziologie und Sozialpsychologie S50:79-86.

Fehr, E. and U. Fischbacher. 2003. "The nature of human altruism." Nature 425:785-791.

Ferragina, E. 2013. "The socio-economic determinants of social capital and the mediating effect of history: Making democracy work revisited." International Journal of Comparative Sociology 54:48-73.

Gamson, William A. 1961. "A theory of coalition formation." American Sociological Review 26:373-382.

Gangl, M. 2006. "Scar effects of unemployment: An assessment of institutional complementarities." American Sociological Review 71:986-1013.

Gelissen, John P. T. M., W. J. H. van Oorschot, and E. Finsveen. 2012. "How does the welfare state influence individuals' social capital? Eurobarometer evidence on individuals' access to informal help." European Societies 14:416-440.

Gesthuizen, M. and P. Scheepers. 2010. "Economic vulnerability among low-educated europeans resource, composition, labour market and welfare state influences." Acta Sociologica 53:247-267.

Gesthuizen, M., T. van der Meer, and P. Scheepers. 2008. "Education and dimensions of social capital: Do educational effects differ due to educational expansion and social security expenditure." European Sociological Review 24:617-632.

Gill, A. 1999. "Government regulation, social anomie and protestant growth in Latin America - a cross-national analysis." Rationality and Society 11:287-316.

Gintis, Herbert. 2000. Game theory evolving. Princeton: Princeton UP.

Goldthorpe, John H. 1996. "The quantitative analysis of large-scale data-sets and rational action theory: For a sociological alliance." European Sociological Review 12:109-126.

- 1998. "Rational action theory for sociology." The British Journal of Sociology 49:167-192.

Hakim, Catherine. 2002. “Lifestyle preferences as determinants of women's differentiated labor market careers." Work and Occupations 29:428-459.

Harslof, I. 2006. "The impact of welfare and labour market institutions on informal recruitment in European youth labour markets." European Societies 8:555-576.

Hechter, M. 1994. "The role of values in rational choice theory." Rationality and Society 6:318-333. 
2004. "From class to culture." American Journal of Sociology 110:400-445.

Hechter, M. and S. Kanazawa. 1997. "Sociological rational choice theory." Annual Review of Sociology 23:191-214.

Hechter, Michael. 1997. "Religion and rational choice theory." Pp. 147-159 in Rational choice theory and religion: Summary and assessment, edited by L. A. Young. New York: Routledge.

Hedström, Peter. 2005. Dissecting the social. On the principles of analytical sociology. Cambridge: Cambridge University Press.

Hedström, Peter and Peter Bearman. 2009a. The Oxford handbook of analytical sociology. Oxford: Oxford University Press.

- 2009b. "What is analytical sociology all about? An introductory essay." Pp. 3-24 in The Oxford handbook of analytical sociology, edited by P. Hedström and P. Bearman. Oxford: Oxford University Press.

Hedström, Peter and Charlotta Stern. 2008. "Rational choice and sociology." Pp. 872-77 in The new Palgrave dictionary of economics, edited by S. N. Durlauf and L. E. Blume. Basingstoke, uk: Palgrave Macmillan.

Heisig, J. P. 2011. "Who does more housework: Rich or poor? A comparison of 33 countries." American Sociological Review 76:74-99.

Homans, George C. 1961. Social behavior: Its elementary forms. New York: Harcourt Brace Jovanovich.

Hook, J. L. 2006. "Care in context: Men's unpaid work in 20 countries, 1965-2003." American Sociological Review 71:639-660.

. 2010. "Gender inequality in the welfare state: Sex segregation in housework, 1965-2003." American Journal of Sociology 115:1480-1523.

Hummell, Hans J. and Karl-Dieter Opp. 1968. "Sociology without sociology. The reduction of sociology to psychology: A program, a test, and the theoretical relevance." Inquiry 11.

Hummelsheim, D. and J. Hirschle. 2010. "Mother's employment: Cultural imprint or institutional governance?” European Societies 12:339-366.

Iannaccone, Laurence R. 1992. "Religious markets and the economics of religion." Social Compass 39:123-131.

- 1994. "Why strict churches are strong." American Journal of Sociology 99:1180-1211.

Jepperson, R. and J. W. Meyer. 2011. "Multiple levels of analysis and the limitations of methodological individualisms." Sociological Theory 29:54-73.

Kaariainen, J. and H. Lehtonen. 2006. "The variety of social capital in welfare state regimes - a comparative study of 21 countries." European Societies 8:27-57.

Kohn, Melvin L. 1987. "Cross-national research as an analytic strategy: American sociological association, 1987 presidential address." American Sociological Review $52: 713-731$ 
Korpi, W. 2001. "Contentious institutions - an augmented rational-action analysis of the origins and path dependency of welfare state institutions in Western countries." Rationality and Society 13:235-283.

Kreidl, M. and B. Hubatkova. 2014. "Does coresidence with grandparents reduce the negative association between sibship size and reading test scores? Evidence from 40 countries." Research in Social Stratification and Mobility 38:1-17.

Kroneberg, Clemens and Frank Kalter. 2012. "Rational choice theory and empirical research: Methodological and theoretical contributions in Europe." Annual Review of Sociology 38:73-92.

Le Donne, N. 2014. "European variations in socioeconomic inequalities in students' cognitive achievement: The role of educational policies." European Sociological Review 30:329-343.

Lehmann, D. 2013. "Religion as heritage, religion as belief: Shifting frontiers of secularism in Europe, the USA and brazil." International Sociology 28:645-662.

Lin, Nan. 1999. "Building a network theory of social capital." Connections 22:28-51.

Lindenberg, Siegwart. 1977. "Individuelle Effekte, kollektive Phänomene und das Problem der Transformation (Individual effects, collective phenomena, and the problem of transformation)." Pp. 46-84 in Probleme der Erklärung sozialen Verhaltens, edited by K. Eichner and W. Habermehl. Meisenheim a.G.: Hain.

1990. "Homo socio-oeconomicus: The emergence of a general model of man in the social sciences.” Journal of Institutional and Theoretical Economics (JITE) / Zeitschrift für die gesamte Staatswissenschaft 146:727-748.

Lindenberg, Siegwart and Reinhard Wippler. 1978. "Theorienvergleich: Elemente der Rekonstruktion (theory comparison: Elements of reconstruction)." Pp. 219-23 in Theorienvergleich in den Sozialwissenschaften, edited by K. O. Hondrich and G. Matthes.

Mahoney, J. 2000. "Path dependence in historical sociology." Theory and Society 29:507-548.

Marx, Karl. [1867] 1993. Capital: A critique of political economy, Edited by E. Mandel and B. Fowkes. Translated by D. Fernbach: Penguin Classics.

Merton, Robert King. [1942] 1966. Social theory and social structure, New York: Free Press.

Montanari, I., K. Nelson, and J. Palme. 2008. "Towards a european social model? Trends in social insurance among EU countries 1980-2000." European Societies 10:787-810.

Montt, G. 2011. "Cross-national differences in educational achievement inequality." Sociology of Education 84:49-68.

Norkus, Z. 2000. "Max Weber's interpretive sociology and rational choice approach." Rationality and Society 12:259-282.

North, Douglas C. 1990. Institutions, institutional change and economic performance. Cambridge: Cambridge UP. 
Opp, Karl-Dieter and Peter Hartmann. 1989. The rationality of political protest: A comparative analysis of rational choice theory. Boulder, Colo.: Westview Press.

Paxton, P. 2002. "Social capital and democracy: An interdependent relationship." American Sociological Review 67:254-277.

- 2007. "Association memberships and generalized trust: A multilevel model across 31 countries." Social Forces 86:47-76.

Putnam, Robert D., Robert Leonardi, and Rafaella Nanetti. 1993. Making democracy work: Civic traditions in modern Italy. Princeton NJ.

Rand, D. G. and M. A. Nowak. 2013. "Human cooperation." Trends in Cognitive Sciences 17:413-425.

Raub, Werner, Vincent Buskens, and Marcel A. L. M. Van Assen. 2011. "Micro-macro links and microfoundations in sociology." The Journal of Mathematical Sociology 35:1-25.

Reimer, D., C. Noelke, and A. Kucel. 2008. "Labor market effects of field of study in comparative perspective an analysis of 22 European countries." International Journal of Comparative Sociology 49:233-256.

Robbins, B. G. 2011. "Neither government nor community alone: A test of statecentered models of generalized trust." Rationality and Society 23:304-346.

Robbins, B. and D. Pettinicchio. 2012. "Social capital, economic development, and homicide: A cross-national investigation." Social Indicators Research 105:519-540.

Rosenfeld, R. and S. F. Messner. 2009. "The crime drop in comparative perspective: The impact of the economy and imprisonment on American and European burglary rates." British Journal of Sociology 60:445-471.

Rössel, Jörg. 2008. "Vom Rationalen Akteur zum 'Systemic Dope': eine Auseinandersetzung mit der sozialtheorie von Hartmut Esser (From rational actor on the 'systemic dope' - a controversy with the social theory of Hartmut Esser)." Berliner Journal für Soziologie 18:156-178.

Rothstein, B. 2001. "The universal welfare state as a social dilemma." Rationality and Society $13: 213-233$.

Rothstein, B. and D. Eek. 2009. "Political corruption and social trust: an experimental approach." Rationality and Society 21:81-112.

Ruiter, S. and F. van Tubergen. 2009. "Religious attendance in cross-national perspective: A multilevel analysis of 60 countries." American Journal of Sociology 115:863-895.

Scheepers, P., M. Gijsberts, and E. Hello. 2002. "Religiosity and prejudice against ethnic minorities in Europe: Cross-national tests on a controversial relationship." Review of Religious Research 43:242-265.

Schlüter, Achim and Insa Theesfeld. 2010. "The grammar of institutions: The challenge of distinguishing between strategies, norms, and rules." Rationality and Society 22:445-475. 
Scholtz, Hanno. 2015. "Institutions and formal game theory." currently under review.

Smith, Adam. [1776] 1976. An inquiry into the nature and causes of the wealth of nations. London: Clarendon.

Sonderskov, K. M. 2011. "Does generalized social trust lead to associational membership? Unravelling a bowl of well-tossed spaghetti." European Sociological Review 27:419-434.

Sonderskov, K. M. and C. Daugbjerg. 2011. "The state and consumer confidence in ecolabeling: Organic labeling in denmark, sweden, the United Kingdom and the United States." Agriculture and Human Values 28:507-517.

Stark, Rodney and Roger Finke. 2000. Acts of faith: Explaining the human side of religion. Berkeley: University of California Press.

Stolz, J. 2010. "A silent battle: Theorizing the effects of competition between churches and secular institutions." Review of Religious Research 51:253-276.

- 2011. "'All things are possible': Towards a sociological explanation of pentecostal miracles and healings." Sociology of Religion 72:456-482.

Teltemann, J. and M. Windzio. 2011. "Die 'kognitive Exklusion' junger Migranten im Ländervergleich: Effekte institutioneller und sozialstruktureller Faktoren." Berliner Journal für Soziologie 21:335-361.

Thompson, Kenneth. [1985] 2005. Readings from Emile Durkheim. London: Routledge.

Udehn, Lars. 2001. Methodological individualism. Background, history, and meaning. London: Routledge.

. 2002. "The changing face of methodological individualism." Annual Review of Sociology 28:479-507.

van der Lippe, T., J. de Ruijter, E. de Ruijter, and W. Raub. 2011. "Persistent inequalities in time use between men and women: A detailed look at the influence of economic circumstances, policies, and culture." European Sociological Review 27:164-179.

van Oorschot, W., W. Arts, and J. Gelissen. 2006. "Social capital in Europe - measurement and social and regional distribution of a multifaceted phenomenon." Acta Sociologica 49:149-167.

van Oorschot, W. and E. Finsveen. 2009. "The welfare state and social capital inequality." European Societies 11:189-210.

Vane, J. and M. Stipkova. 2013. "The national religious environment and the orthodoxy of Christian beliefs: A comparison of Austria, the Czech Republic and Slovakia." Sociologicky Casopis-Czech Sociological Review 49:403-425.

Verwiebe, R. and B. Riederer. 2013. "Die Lesekompetenzen von Jugendlichen mit Migrationshintergrund in westlichen Gesellschaften. Eine Mehrebenenanalyse auf Basis der PISA-Studie von 2000 bis 2009." "The reading literacy of immigrant youth in Western societies a multilevel analysis based on PISA 2000 to 2009." Zeitschrift für Soziologie 42:201-221. 
Vinacke, W. Edgar and Abe Arkoff. 1957. "An experimental study of coalitions in the triad." American Sociological Review 22:406-414.

Vrooman, J. C. 2012. "Regimes and cultures of social security: Comparing institutional models through nonlinear PCA." International Journal of Comparative Sociology $53: 444-477$.

Walras, Léon. 1874. Eléments d'économie politique pur ou théorie de la richesse sociale. Lausanne: Corbaz.

Weber, Max. 1922. Wirtschaft und Gesellschaft. Tübingen: Mohr (Siebeck).

Young, Lawrence Alfred. 1997. Rational choice theory and religion: Summary and assessment. New York: Routledge.

Zafirovski, M. 1999. "Unification of sociological theory by the rational choice model: Conceiving the relationship between economics and sociology." Sociology-the Journal of the British Sociological Association 33:495-514.

- 2000. "The rational choice generalization of neoclassical economics reconsidered: Any theoretical legitimation for economic imperialism?" Sociological Theory 18:448-471. 